\title{
HAMBURG UNIVERSITY RADIOCARBON DATES II
}

\section{H W SCHARPENSEEL and H SCHIFFMANN}

Ordinariat für Bodenkunde der Universität Hamburg

Radiocarbon measurements mainly on soil samples and soil organic matter fractions are being continued. Sample benzene preparation follows Scharpenseel \& Pietig (1969; 1970a). Radioactivity is measured in single screw cap quartz vials using a Packard Tri-Carb 3075 as well as a Berthold Betaszint BF 5000 .

\section{ACKNOWLEDGMENTS}

Technical assistance by $\mathbf{B}$ Hintze, $\mathrm{H}$ Krogmann, E Kruse, T Manukyan, and E Wiedemann is gratefully acknowledged. This work was supported by the Federal Department of Research and Technology.

\section{SAMPLE DESCRIPTIONS}

$$
\text { I. SOIL SAMPLES }
$$

Pretreatment of soil samples described in Scharpenseel \& Pietig (1969), and Scharpenseel (1972).

\section{A. Germany}

Sequence of mud, topped by low moor peat and sand cover at fringes of refilled old river bed of Ems R. In adjacent sandy bank of Ems R artifacts of ren hunter group (Ahrensberg culture) dated ca 9000 BC. Samples to determine approx age of low moor.

HAM-280. Rietberg $\left(51^{\circ} 48^{\prime} \mathrm{N}, 8^{\circ} 25^{\prime} \mathrm{E}\right)$, mud, $30.3 \% \quad 6680 \pm 90$ organic

HAM-281. Rietberg, low moor, $80 \%$ organic

Samples coll and subm 1975 by H Mertens, Geol Landesamt NRW, Krefeld. Comment: dates indicate time of development of mud and low moor, which overlie archaeol predated river bank planum.

Brown earth (ochrept) profile rich in humus down to deep layers on terrace gravel.

HAM-631. Holzkirchen, near Munich-Salzburg Hwy, $\quad 117.3 \pm 0.6 \%$ $47^{\circ} 55^{\prime} \mathrm{N}, 11^{\circ} 43^{\prime} \mathrm{E}$ ), Ahl 0 to $5 \mathrm{~cm}$

HAM-632. Ah2 5 to $25 \mathrm{~cm}$

$$
105.1 \pm 0.5 \%
$$

HAM-633. Ah3 25 to $45 \mathrm{~cm}$

$$
2510 \pm 50
$$

HAM-634. Bt 45 to $65 \mathrm{~cm}$

$$
123.8 \pm 0.8 \%
$$

Samples coll and subm 1975 by $\mathrm{H}$ Grottenthaler, Bayer Geol Landesamt, Munich, FRG. Comment: samples reworked or contaminated, bomb $\mathrm{C}$ at depth of 45 to $65 \mathrm{~cm}$.

$$
\text { B. Argentina }
$$

Brunizem soils from Argentina (Udolls with argillic horizon) 
HAM-231. Brunizem, Profile B 5, Rafaela $96 \mathrm{~m}$ alt, $\left(31^{\circ}\right.$ $110.0 \pm 0.5 \%$ $\left.15^{\prime} \mathrm{S}, 61^{\circ} 27^{\prime} \mathrm{W}\right)$, typical Brunizem with $\mathrm{B}_{2}{ }^{-}$ horizon, sampling after crop of corn, Ap 0 to $15 \mathrm{~cm}$

HAM-232. Ah/AhBv 15 to $30 \mathrm{~cm}$

$320 \pm 60$

HAM-233. Btl 30 to $40 \mathrm{~cm}$

$114.7 \pm 0.5 \%$

HAM-234. Bt1 40 to $50 \mathrm{~cm}$

HAM-235. Bt1 50 to $60 \mathrm{~cm}$

$101.1 \pm 0.4 \%$

$260 \pm 70$

HAM-236. Bt2 60 to $70 \mathrm{~cm}$

$104.3 \pm 0.5 \%$

$480 \pm 80$

HAM-237. Bt2/Bt3 70 to $80 \mathrm{~cm}$

HAM-238. Typical Brunizem, profile B 7, Esperanza $38 \mathrm{~m}$ alt $\left(31^{\circ} 26^{\prime} \mathrm{S}, 61^{\circ} 87^{\prime} \mathrm{W}\right)$, experimental plot, Ap 0 to $13 \mathrm{~cm}$

HAM-239. Ah 15 to $30 \mathrm{~cm}$

$200 \pm 60$

HAM-240. AhBv 30 to $40 \mathrm{~cm}$

HAM-241. Bt1 40 to $50 \mathrm{~cm}$

HAM-242. Bt1 50 to $60 \mathrm{~cm}$

HAM-243. Bt2 60 to $70 \mathrm{~cm}$

HAM-244. Bt2 70 to $80 \mathrm{~cm}$

$113.8 \pm 0.6 \%$

HAM-245. Slightly planosolic Brunizem, profile B 8, Angel Gallardo, $16 \mathrm{~m}$ alt $\left(31^{\circ} 33^{\prime} \mathrm{S}, 60^{\circ} 43^{\prime} \mathrm{W}\right)$ weed covered fallow, Ap 0 to $10 \mathrm{~cm}$

HAM-246. Ap/P/Ah 10 to $30 \mathrm{~cm}$

$101.1 \pm 0.4 \%$

$980 \pm 60$

HAM-247. AlBv 30 to $40 \mathrm{~cm}$

$1930 \pm 140$

HAM-248. Btl 40 to $50 \mathrm{~cm}$

HAM-249. Bitl 50 to $60 \mathrm{~cm}$

$2110 \pm 80$

$2420 \pm 80$

HAM-250. Bt1 60 to $70 \mathrm{~cm}$

$2550 \pm 70$

HAM-251. Btl 70 to $80 \mathrm{~cm}$

$2780 \pm 80$

HAM-252. Bt2 80 to $90 \mathrm{~cm}$

$112.8 \pm 0.5 \%$

HAM-253. Brunizem under cropping pattern, till $30 \mathrm{~cm}$ rooted, fragipan, Profile B 9, Villa Conception des Tio, $110 \mathrm{~m}$ alt $\left(31^{\circ} 33^{\prime} \mathrm{S}, 60^{\circ} 43^{\prime} \mathrm{W}\right)$, Ap 0 to $15 \mathrm{~cm}$

HAM-254. Ah/B 18 to $27 \mathrm{~cm}$

$460 \pm 60$ 


$\begin{array}{lllr}\text { HAM-255. } & \text { Bt } & 27 \text { to } 35 \mathrm{~cm} & 1080 \pm 100 \\ \text { HAM-256. } & \text { Bv } & 35 \text { to } 45 \mathrm{~cm} & 1370 \pm 90 \\ \text { HAM-257. } & \text { Bv } & 45 \text { to } 55 \mathrm{~cm} & 1870 \pm 90\end{array}$

Samples coll and subm 1974 by S Stephan, Inst Soil Sci, Bonn Univ, FRG. Comment: dates of deepest humus containing fringes younger than 5000 to 6000 BP as found in Holocene Mollisols of N Europe (Scharpenseel, 1972). Pronounced clay infiltration carrying organic matter could be responsible for some rejuvenation.

\section{Tunisia}

Fossil soil horizons in Bou Huertma alluvium ( $\left.36^{\circ} 37^{\prime} \mathrm{N}, 8^{\circ} 55^{\prime} \mathrm{E}\right)$.

HAM-258. Pit hole in alluvium $2 \mathrm{~km} \mathrm{~N} \mathrm{Hwy,} 1 \% \mathrm{C}, 110 \mathrm{~cm} \quad 3400 \pm 80$

HAM-259. Same site, $1.1 \% \mathrm{C}, 160 \mathrm{~cm}$

$4930 \pm 80$

Samples coll and subm 1974 by K Kirschey, Ordinariat $\mathrm{f}$ Bodenkunde, Hamburg Univ, FRG. Supporting samples for series HAM-157-174 (R, v 18, p 282-283). Comment: samples indicate time of soil formation in Medjerdah-Bou Huertma alluvial deposits.

\section{Humic acid samples of Lower Saxonian soils}

Humic acid samples, produced by continuous extraction from various soil materials (especially from peaty, podzolic or chernozemic soil materials) using alkaline and neutral extractants. Peat samples of surface near origin from spots unaltered by recent human activities (peat cutting, recultivation). All soils sampled within boundaries of Lower Saxoniastate, between Elbe $\mathrm{R}$ and Ems R.

HAM-260. Humic acid sample, Sonnenberger Moor, high $\quad 180 \pm 70$ moor, Harz, Vaccinium vegetation.

HAM-261. Fringes of Sonnenberger Moor, high moor, $\quad 1210 \pm 100$ Picea vegetation.

HAM-262. Teufelsmoor near Bremen, high moor, $\quad 3210 \pm 100$ "white peat".

HAM-263. Gnarrenburger Moor, highly decomposed $\quad 1610 \pm 80$ "black peat".

HAM-264. Königsmoor near Bremen, high moor, $\quad 2430 \pm 80$ "white peat", $30 \mathrm{~cm}$.

HAM-265. Königsmoor near Bremen, albic horizon in $\quad 2350 \pm 70$ sand below peat of high moor

HAM-266. Königsmoor near Bremen, spodic horizon in $2770 \pm 100$ sand and peat, spodosol underneath high moor

$4200 \pm 110$ 
HAM-268. Highly decomposed low moor peat from Lake Dümmer near Hannover

HAM-269. Moderately decomposed low moor peat near $3330 \pm 90$ Stade I

HAM-270. Highly decomposed low moor peat near Stade II

HAM-271. Highly decomposed low moor peat from "großer Bruch" near Jerxheim, calcareous site $\left(30 \% \mathrm{CaCO}_{3}\right)$

HAM-272. Erica Podzol, spodic horizon, Vogtei, pH 7 extract

HAM-273. Erica Podzol, spodic horizon, Vogtei, pH 14extract

HAM-274. Calluna Podzol, spodic horizon, Steyerberg, $\mathrm{pH}$ 14-extract

HAM-275. Brown coal (Kasseler Braun) Steinberg, Hannoversch Münden

$$
2670 \pm 80
$$$$
2480 \pm 100
$$

$730 \pm 80$

$650 \pm 80$

$230 \pm 90$

$19,800 \pm 710$

$18,210 \pm 670$

HAM-276. Peaty sand from sand pit Honerdingen near Walsrode, Südheide

HAM-277. Argiudoll near Hildesheim, field culture, Ap $10 \mathrm{~cm}$

$340 \pm 80$

$230 \pm 80$

HAM-278. Argiudoll near Hildesheim, forest, Ah $10 \mathrm{~cm}$

HAM-279. Argiudoll near Hildesheim, forest, Ah $35 \mathrm{~cm} 103.6 \pm 0.6 \%$
Samples coll and subm 1974 by W Rochus, Interfak Lehrgebiet Chemie, Göttingen Univ, FRG. Comment: near surface samples from Sonnenberger High Moor seem to be influenced by contemporary and bomb carbon sources. The Königsmoor samples (HAM-264-266) belong to high moor superimposed on pronounced Spodosol. Peat and albic horizon-C are slightly younger than carbon of the accumulating spodic horizon. This is a "wurzelechtes Hochmoor," which means that plants producing peat are still rooted in mineral soil. Almost equal age of peaty, albic and spodic horizon confirms this model; equal age reflects uniform supply to all horizons with modern $\mathrm{C}$ by deeply rooting plants. Among the low moor peats the one from the calcareous Jerxheim site with the fastest turnover of organic matter is dated youngest. The Podzol samples are all highly rejuvenated by organic leachates. Organic matter in basal sands of sand pit Honerdingen is relic of former patches of peat, covered by Pleistocene fine sands. If no leaching of organic matter through 6 to $8 \mathrm{~m}$ dune sand did occur, date indicates age of dune sand deposition (Rochus, 1975). Brown coal from Steinberg should consist of dead carbon. Date indicates admixture of younger organic constituents. Humic acid 
from Chernozem near Hildesheim originates from near surface samples, rejuvenated with modern $\mathrm{C}$ and influenced by bomb carbon.

II. FRACTIONS OF SOIL ORGANIC MATTER

Podzol (Spodosol) from Gravel pit Weber, Scherpenseel, near Dutch border $\left(50^{\circ} 56^{\prime} \mathrm{N}, 6^{\circ} 1^{\prime} \mathrm{E}\right)$. Fractionation of $\mathrm{Na}$-pyrophosphate/ $\mathrm{NaOH}$ extract by Sephadex G 50 gel permeation.

HAM-282. Podzol Scherpenseel, average sample, Bh $105 \quad 2470 \pm 70$ to $130 \mathrm{~cm}$

HAM-283. Total Na-pyrophosphate/NaOH extract of $\quad 2940 \pm 60$ same sample, extracted under protective gas and precipitated by $\mathrm{HCl}$

HAM-284. Same sample eluate after passage through $\quad 2230 \pm 70$ $100 \mathrm{~cm}$ column of Sephadex G 50

HAM-285. Same sample, Sephadex G 50, retained/ $\quad 5410 \pm 90$ delayed fraction

Samples prepared and subm 1975 by H W Scharpenseel and E Kruse, Inst Soil Sci, Bonn Univ, FRG. Related samples: BONN-90 (R, v 10, p 20), BONN-1688-1698 (R, v 15, p 267). Comment: Sephadex fractionation indicates selective enrichment of smaller-sized retained fraction with older $\mathrm{C}$ compared to larger-sized passing fraction with relatively younger $\mathrm{C}$.

Chernozem (Mollisol) from Aseler Wald near Hildesheim $\left(52^{\circ} 10^{\prime} \mathrm{N}\right.$, $\left.10^{\circ} 1^{\prime} \mathrm{E}\right)$. Production of organic matter fractions by benzene extraction, classical fractionation according to Flaig et al (1955), Sephadex gel permeation and acid hydrolysis.

HAM-286. Aseler Wald, C of soil in total, AC 55 to $65 \mathrm{~cm}$

$$
\begin{array}{r}
2470 \pm 60 \\
3220 \pm 80 \\
370 \pm 70 \\
380 \pm 70 \\
2100 \pm 70 \\
1480 \pm 60 \\
2940 \pm 90 \\
2460 \pm 60 \\
151.6 \pm 0.8 \% \\
124.8 \pm 0.6 \% \\
2920 \pm 70
\end{array}
$$

HAM-292. Humic acid, Sephadex G 50, retained/ delayed fraction

HAM-293. Humines

HAM-299. Humines, Sephadex G 75, retained/ delayed fraction

HAM-295. Humus coal 
HAM-296. $6 \mathrm{~N} \mathrm{HCl} \mathrm{hydrolysis} \mathrm{of} \mathrm{whole} \mathrm{soil,} \mathrm{dissolved}$ part
$104.4 \pm 0.5 \%$

$$
3160 \pm 70
$$

HAM-297. $6 \mathrm{~N} \mathrm{HCl} \mathrm{hydrolysis} \mathrm{of} \mathrm{whole} \mathrm{soil,} \mathrm{residue}$

Samples and fractions prepared and subm 1975 by H W Scharpenseel and $\mathrm{E}$ Kruse. Related samples from a site nearby. BONN-1809-1811 (R, v 15, p 266). Comment: as expected, age of fulvic acids is lower than of humic acids and humines. The retained fraction due to Sephadex G50 permeation is older than leaching fraction. Sephadex fractionation of humines in Sephadex G 75 failed. Some of the column filling of G 75 was not quite new. Microbial decay products apparently transferred bomb carbon into sample fractions. Humus coal is oldest of classical fractions. Benzene extracted lipids are older as Grant-Taylor (1972) reported before. The gap between hydrolysate and hydrolysis residue, found already by Paul et al (1964) seems most encouraging to do more hydrolysis fractionation work with other soil materials in order to establish a correction method for rejuvenated soil samples.

Fossil A horizon in Würmian loess, on top trachyt tuff from Alleröd volcanism, Mendig, near Laach L $\left(50^{\circ} 24^{\prime} \mathrm{N}, 7^{\circ} 17^{\prime} \mathrm{E}\right)$. Some rejuvenation by deep roots. Production of organic matter fractions by classical fractionation (Flaig et al, 1955), Sephadex gel permeation, benzene extraction and acid hydrolysis.

HAM-298. Mendig, gravel pit Xaver Michels, fA $180 \quad 10,600 \pm 120$ to $190 \mathrm{~cm}$, C of soil in total

HAM-300. Benzene extracted lipids and waxes $\quad 4130 \pm 100$

HAM-301. Fulvic acids, undialized $\quad 1140 \pm 200$

HAM-302. Fulvic acids, dialized $\quad 136.3 \pm 0.8 \%$

HAM-303. Humic acids $\quad 6970 \pm 210$

HAM-304. Humic acids, Sephadex G 50, passing fraction $\quad 6110 \pm 100$

HAM-305. Humic acids, Sephadex G 50, retained/ $\quad 6830 \pm 130$ delayed fraction

HAM-306. Humines $\quad 10,320 \pm 140$

HAM-307. Humus coal $\quad 9940 \pm 140$

HAM-308. $6 \mathrm{~N} \mathrm{HCl}$ hydrolysis of whole soil, dissolved part $2510 \pm 100$

HAM-309. $6 \mathrm{~N} \mathrm{HCl} \mathrm{hydrolysis} \mathrm{of} \mathrm{whole} \mathrm{soil,} \mathrm{residue} \quad 11,360 \pm 150$

HAM-310. Charcoal 10,330 \pm 120

Samples and fractions prepared and subm 1975 by H W Scharpenseel and E Kruse. Samples dated from pedogenetically same horizon few $\mathrm{km}$ apart: BONN-96 (R, v 10, p 16), BONN-763 (R, v 12, p 35), BONN1681-1684 (R, v 15, p 266). Comment: ages of fulvic acids and soil hy- 
drolysate are youngest. Dialized fulvic acids seem to be contaminated. Benzene extracted lipids did not show older age as in preceding sample from Aseler Wald (HAM-287). Humines, humus coal and charcoal are distinctly older than other samples. Widest gap is between carbon from acid hydrolysate and hydrolysis residue. Latter fraction is relatively oldest of the whole series.

Highly clayey low moor soil, vertic during very dry summers, Koislhof, lower terrace of Isar R. Production of organic matter fractions by stepwise extraction of soil in Soxhlet-extractors by means of solvents with increasing polarity, by clasical fractionation (Flaig et al, 1955), Sephadex gel permeation and acid hydrolysis.

HAM-318. Low moor soil Koislhof, $38 \%$ C, Hn 50 to $\quad 7200 \pm 210$ $80 \mathrm{~cm}$, total soil

HAM-311. Petroleum benzene extracted C of same sample $3290 \pm 320$

HAM-312. Benzene extracted Sample C $\quad 6630 \pm 130$

HAM-313. Methanol extracted Sample C $\quad 6380 \pm 90$

HAM-314. Acetone extracted Sample C (extremely small $4020 \pm 360$ sample, questionable)

HAM-315. Acetonitrile extracted Sample C (extremely $2240 \pm 440$ small sample, questionable)

HAM-316. Dimethylformamide extracted Sample C $\quad 10,760 \pm 130$

HAM-317. Dimethylsulfoxide extracted Sample C ? $13,140 \pm 200$

HAM-319. $6 \mathrm{~N} \mathrm{HCl} \mathrm{hydrolysis} \mathrm{of} \mathrm{whole} \mathrm{soil,} \mathrm{dissolved} \mathrm{part} 7270 \pm 140$

HAM-320. $6 \mathrm{~N} \mathrm{HCl} \mathrm{hydrolysis} \mathrm{of} \mathrm{whole} \mathrm{soil,} \mathrm{residue} \quad 9730 \pm 170$

HAM-321. Fulvic acids after previous extraction with $\quad 6860 \pm 250$ organic solvents

HAM-322. Fulvic acids, same origin, but dialized $\quad 7060 \pm 110$

$\begin{array}{ll}\text { HAM-323. Humic acids } & 8810 \pm 120\end{array}$

HAM-324. Humic acids, Sephadex G 50, passing fraction $7590 \pm 120$

HAM-325. Humic acids, Sephadex G 50, retained/delayed $7820 \pm 90$ fraction

HAM-326. Humines

$7110 \pm 110$

HAM-327, 328. Humines fractionated by Sephadex G 75, microbiologically contaminated just as HAM-294, 299, above.

HAM-329. Humus coal $7230 \pm 110$

Samples and fractions prepared and subm 1975 by H W Scharpenseel and E Kruse. Samples dated from same location: HAM-14-21, HAM-65 
( $\mathrm{R}, \mathrm{v}$ 18, pp 269, 273). Comment: organic solvent extraction is unrewarding for concentration of older Sample C. Tiny acetone and acetonitrile extracted C samples are unreliable. Dimethylformamide and dimethysulfoxide extracted $\mathrm{C}$ is contaminated with petrochemical solvent $\mathrm{C}$, proven by $\Delta^{13} \mathrm{C}$ measurement, despite thorough vacuum drying of soil after extractions $\left(\Delta^{13} \mathrm{C}\right.$ measurements were carried out by $\mathrm{H}$ Willkomm, Kiel Univ). In this sample classical fractionation and also Sephadex column fractionation as well as acid hydrolysis were carried out on soil material previously subjected to the stepwise extraction process by organic solvents of increasing polarity. This apparently reduced differences among other fractions. Age difference between fulvic acids and humic acids, humines, humus coal is small. For details see Scharpenseel (1976).

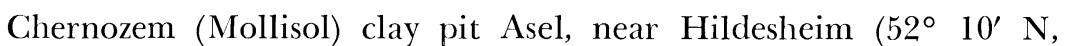
$\left.10^{\circ} 1^{\prime} \mathrm{E}\right)$. Organic matter fractions obtained by repeated $6 \mathrm{~N}$ HCl hydrolysis. One aliquot of each repetitious hydrolysis treatment measured.

HAM-623. Asel, whole soil, Ah 35 to $45 \mathrm{~cm}$

$$
\begin{array}{r}
>100 \% \\
>100 \% \\
2530 \pm 80 \\
2410 \pm 70 \\
2340 \pm 80 \\
2770 \pm 80 \\
2560 \pm 90 \\
2960 \pm 80 \\
3260 \pm 100
\end{array}
$$

HAM-624. 1. step of 6 N HCI hydrolysis, residue

HAM-626. 3. step of $6 \mathrm{~N} \mathrm{HCl} \mathrm{hydrolysis,} \mathrm{residue}$

HAM-627. 4. step of $6 \mathrm{~N} \mathrm{HCl} \mathrm{hydrolysis,} \mathrm{residue}$

HAM-628. 5. step of $6 \mathrm{~N} \mathrm{HCl}$ hydrolysis, residue

HAM-629. 6. step of $6 \mathrm{~N} \mathrm{HCl} \mathrm{hydrolysis,} \mathrm{residue}$

HAM-630. 7. step of $6 \mathrm{~N} \mathrm{HCl} \mathrm{hydrolysis,} \mathrm{residue}$

Samples and fractions prepared and subm 1976 by $\mathrm{H} \mathrm{W}$ Scharpenseel and $\mathrm{T}$ Manukyan, Ordinariat f Bodenkunde, Hamburg Univ, FRG. For dates from nearby sites, see Aseler Wald series, above, HAM-286-297. Comment: not including the bomb-carbon-dominated samples, repeated hydrolysis treatment produced age increases of ca $30 \%$ by increasing removal of acid soluble younger components.

Gleyey transition of Mollisol to histosol Ergolding, near Landshut $\left(48^{\circ} 35^{\prime} \mathrm{N}, 12^{\circ} 12^{\prime} \mathrm{E}\right)$. Production of organic matter fractions by repeated acid hydrolysis. One aliquot of each repetitious hydrolysis treatment subjected to dating.

HAM-782. Ergolding, AhHn 50 to $60 \mathrm{~cm}$, whole soil $4640 \pm 90$

HAM-800. Whole soil, but pyrolized under $\mathrm{N}_{2}$ before $4570 \pm 110$ combustion

HAM-783. 1. step of $6 \mathrm{~N} \mathrm{HCl} \mathrm{hydrolysis,} \mathrm{residue}$ $5610 \pm 80$

HAM-784. 2. step of $6 \mathrm{~N} \mathrm{HCl}$ hydrolysis, residue $5820 \pm 110$ 
HAM-785. 3. step of $6 \mathrm{~N} \mathrm{HCl}$ hydrolysis, residue

$$
\begin{array}{r}
5700 \pm 100 \\
5540 \pm 110 \\
6110 \pm 90 \\
5790 \pm 90
\end{array}
$$

HAM-786. 4. step of $6 \mathrm{~N} \mathrm{HCl} \mathrm{hydrolysis,} \mathrm{residue}$

HAM-787. 5. step of $6 \mathrm{~N} \mathrm{HCl} \mathrm{hydrolysis,} \mathrm{residue}$

HAM-788. 6. step of $6 \mathrm{~N} \mathrm{HCl} \mathrm{hydrolysis,} \mathrm{residue}$

Samples and fractions prepared and subm 1976 by H W Scharpenseel and $\mathrm{T}$ Manukyan. Comment: again, by repeated hydrolysis treatment ca $30 \%$ of initial age was added by removing younger acid soluble components. Pretreatment of recent soil samples by repeated acid hydrolysis appears to be a useful preparation technique.

III. GEOLOGIC AND GEOGRAPHIC SAMPLES

Loose dune material with roots of Nebka forming plants (Ziziphus spec.), from dune (Nebka), near wheat cultivation, Rabta, Ben Aoun, Tunisia (34 $\left.47^{\circ} \mathrm{N}, 9^{\circ} 11^{\prime} \mathrm{E}\right)$. Dead Ziziphus roots could indicate age of Nebka formation, which indicates desertification progress.

HAM-717. Dune sand with roots of Ziziphus sp, Sample $2 \quad 550 \pm 90$

HAM-718. Dune sand with roots of Ziziphus sp, Sample $3 \quad 160 \pm 70$

HAM-764. Dune sand with roots of Ziziphus sp, Sample $4 \quad 142.2 \pm 0.6 \%$

Samples coll and subm 1975 by $\mathrm{H}$ Mensching, Geog Inst, Hamburg Univ, FRG. Comment: very young ages of Ziziphus roots indicate desertification progress in recent period of time. More samples will be tested. Sea.

Sea level-coast line studies based on peat dating, shore of Northern

HAM-765. Start of peat growth, deepest position, -82 to $4240 \pm 130$ $-88 \mathrm{~cm}$, bore hole $8 / 74\left(53^{\circ} 51^{\prime} \mathrm{N}, 8^{\circ} 34^{\prime} \mathrm{E}\right)$

HAM-767. Start of peat growth on terrace, +101 to $+89 \mathrm{~cm}$, bore hole $10 / 75\left(53^{\circ} 50^{\prime} \mathrm{N}, 8^{\circ} 34^{\prime} \mathrm{E}\right)$

HAM-768. Start of peat growth on terrace, +160 to $+155 \mathrm{~cm}$, bore hole $4 / 75\left(53^{\circ} 50^{\prime} \mathrm{N}, 8^{\circ} 34^{\prime} \mathrm{E}\right)$

HAM-769. Start of peat growth on terrace, +90 to $+84 \mathrm{~cm}$, bore hole $3 / 75\left(53^{\circ} 50^{\prime} \mathrm{N}, 8^{\circ} 34^{\prime} \mathrm{E}\right)$

HAM-770. Basal peat, red brown, +16 to $+11 \mathrm{~cm}$, bore hole $8 / 74\left(53^{\circ} 51^{\prime} \mathrm{N}, 8^{\circ} 34^{\prime} \mathrm{E}\right)$

HAM-771. Basal peat, red brown, +30 to $+23 \mathrm{~cm}$, bore $\quad 3760 \pm 100$ hole $2 / 75\left(53^{\circ} 50^{\prime} \mathrm{N}, 8^{\circ} 34^{\prime} \mathrm{E}\right)$

HAM-772. Basal peat, red brown, +144 to $+134 \mathrm{~cm}$, bore $\quad 3580 \pm 90$ hole $10 / 75\left(53^{\circ} 50^{\prime} \mathrm{N}, 8^{\circ} 34^{\prime} \mathrm{E}\right)$

HAM-773. Basal peat, red brown, +177 to $+172 \mathrm{~cm}$, bore $6130 \pm 240$ hole $4 / 75\left(53^{\circ} 50^{\prime} \mathrm{N}, 8^{\circ} 34^{\prime} \mathrm{E}\right)$ 
HAM-774. Basal peat, red brown, +107 to $+109 \mathrm{~cm}$, bore hole $25 / 75\left(53^{\circ} 50^{\prime} \mathrm{N}, 8^{\circ} 34^{\prime} \mathrm{E}\right)$

HAM-775. Highest occurrence of peat, +192 to $+187 \mathrm{~cm}, \quad 3820 \pm 90$ bore hole $4 / 75\left(53^{\circ} 50^{\prime} \mathrm{N}, 8^{\circ} 34^{\prime} \mathrm{E}\right)$

HAM-776. End of peat growth, +57 to $+52 \mathrm{~cm}$, bore hole $8 / 74\left(53^{\circ} 51^{\prime} \mathrm{N}, 8^{\circ} 34^{\prime} \mathrm{E}\right)$

$3210 \pm 80$

Samples coll and subm 1975 by G Linke, Hamburg Geol Landesamt, Hamburg, FRG. Comment: ages of peat samples at well defined levels will be used in context with other experimental data to determine coast line chronology.

Humus containing alluvial clay from Elbe R alluvium, BillwerderAllermöhe, S Hamburg, measurement of date of deposition.

HAM-791. Alluvium of Elbe R, Billwerder-Allermöhe, $\quad 1590 \pm 80$ construction pit, cross rds Marshhwy and Oberer Landweg, $\left(53^{\circ} 28^{\prime} \mathrm{N}, 10^{\circ} 10^{\prime} \mathrm{E}\right)$, peat, 115 to $130 \mathrm{~cm}$ below surface

HAM-792. Same site, tree bark and branches, 115 to $130 \mathrm{~cm} \quad 1770 \pm 90$

HAM-793. Same site, some leaves embedded in alluvial clay $2720 \pm 100$

HAM-794. Profile pit on highest level of vaulted field, $\quad 1650 \pm 80$ alluvium of Elbe R, Billwerder-Allermöhe $\left(53^{\circ} 28^{\prime} \mathrm{N}, 10^{\circ} 11^{\prime} \mathrm{E}\right), 66$ to $75 \mathrm{~cm}$, humus-rich alluvial clay

HAM-795. Same site, 75 to $83 \mathrm{~cm}$, alluvial clay, very rich in humus

HAM-796. Same site, 83 to $96 \mathrm{~cm}$, alluvial clay, very rich in humus

HAM-797. Another profile pit on highest level of vaulted $\quad 3170 \pm 100$ field, alluvium of Elbe R, BillwerderAllermöhe $\left(53^{\circ} 28^{\prime} \mathrm{N}, 10^{\circ} 11^{\prime} \mathrm{E}\right), 74$ to $76 \mathrm{~cm}$, humus containing alluvial clay

HAM-798. Same site, 76 to $79 \mathrm{~cm}$, humus containing alluvial clay

HAM-799. Same site, 79 to $82 \mathrm{~cm}$, humus containing $\quad 3370 \pm 100$ alluvial clay

Samples coll, subm, prepared, and measured 1976 by B Hintze, Ordinariat Soil Sci, Hamburg Univ, FRG. Comment: profile HAM-797799 overlain by shallow extremely clayey layer, impeding rejuvenation from above by root growth, animal transport, infiltration through cracks. This clay protection does not exist in profile HAM-794-796. Furthermore, humus containing alluvial clay continues below depth of profile pits. 
Analogous layers in different pits need not be located at same depth. Age $>3000$ indicates at least Sub-boreal deposition of those alluvial clays, now found at 70 to $85 \mathrm{~cm}$ depth.

\section{ARCHAEOLOGIC SAMPLES}

HAM-622. Wood sample of Celtic boat, from con$1580 \pm 60$ struction pit near Frankfurt, Germany $\left(50^{\circ} 4^{\prime} \mathrm{N}, 8^{\circ} 4 \mathrm{l}^{\prime} \mathrm{E}\right)$. Sample coll and subm 1975 by H Zakosek, Inst Soil Sci, Bonn Univ, FRG.

Comment: since Celts had already left Germany at the end of LaTène period, date is slightly younger than expected.

\section{Inclan series, Peru}

HAM-602. Charcoal, Inclan, Dist Sama Grande,
Prov Tacna, Dept Tacna $\left(17^{\circ} 45^{\prime} \mathrm{S}\right.$, $850 \pm 60$ $\left.70^{\circ} 15^{\prime} \mathrm{W}\right)$, charcoal, $155 \mathrm{~cm}$ below desert sand surface

HAM-603. Vegetable coal, $110 \mathrm{~cm}$ below desert $740 \pm 70$ sand surface

HAM-604. Charcoal, $110 \mathrm{~cm}$ below desert sand surface

HAM-605. Textile fragment, $40 \mathrm{~cm}$ below desert sand surface

$143.6 \pm 1.5 \%$

$$
400 \pm 70
$$

HAM-606. Wooden remains, $90 \mathrm{~cm}$ below desert sand surface

HAM-607. Charcoal, $100 \mathrm{~cm}$ below desert sand surface

$124.6 \pm 1.1 \%$

HAM-608. Wooden relics, $100 \mathrm{~cm}$ below desert sand surface

HAM-609. Charcoal, $130 \mathrm{~cm}$ below desert sand surface

HAM-610. Wood, $100 \mathrm{~cm}$ below desert sand surface $920 \pm 80$ next to collapsed bldg

\section{Quebrada de la Vaca series, Peru}

HAM-611. Vegetable cane, Quebrada de la Vaca, Dist Chala, Prov Caraveli, Dept Arequipa, Peru $\left(13^{\circ} 48^{\prime} \mathrm{S}, 74^{\circ} 24^{\prime} \mathrm{W}\right), 80 \mathrm{~cm}$ below floor inside storage bldg

HAM-612. Cotton and cotton seeds from sand filled $103.3 \pm 0.9 \%$ $150.0 \pm 2.0 \%$ storage bldg, small sample 
HAM-613. Wood, $60 \mathrm{~cm}$ below collapsed bldg surrounded by desert sand

HAM-614. Chili pepper, at base of stone-constructed storage bldg, locked by stones

HAM-615. Charcoal, $140 \mathrm{~cm}$ below floor in storage $130.5 \pm 2.7 \%$ bldg

HAM-616. Wool fibers in circular storage bldg, $>100 \%$ small sample

HAM-617. Remains of textile fabric, $80 \mathrm{~cm}$ below $101.9 \pm 0.9 \%$ floor in sand-filled storage bldg

HAM-618. Cotton sample in pot dug out of sand

$$
\begin{array}{r}
101.2 \pm 1.0 \% \\
90 \pm 110
\end{array}
$$

HAM-619. Charcoal, $50 \mathrm{~cm}$ depth, below desert sand in rubbish pile

HAM-620. Guano (bird dung) in guano filled storage bldg

$164.5 \pm 1.6 \%$

HAM-621. Dung remains from $100 \mathrm{~cm}$ depth in $360 \pm 80$ storage bldg

Samples coll and subm 1975 by H Trimborn and R Santos Ramirez, Inst f Völkerkunde, Bonn Univ, FRG. Comment: samples of site Inclan, Sama Grande, Tacna, are from still existing supposedly pre-Spanish settlement. Dates from 670 to $920 \mathrm{yr}$ confirm this supposition, some samples are modern and contain bomb carbon. Sample site Quebrada de la Vaca, Chala was previously studied: BONN-1659-1661 (R, v 16, p 163). These 3 charcoal samples were dated at AD 860 to 1130, pre-Spanish. HAM-611-621, except for HAM-613, are all younger, post-Spanish, most of them even modern with bomb carbon. Most samples $>100 \%$ are textile fabrics and fibers, seeds or dung.

\section{REFERENCES}

Flaig, W, Scheffer, F, and Klamroth, B, 1955, Zur Charakterisierung der Huminsäuren des Bodens: Zeitschr Pflanzenernähr, Bodenkunde, v 71, p 33

Grant-Taylor, T L 1972, The extraction and use of plant lipids as a material for radiocarbon dating: 8th internatl conf on radiocarbon dating, Proc, Wellington, New Zealand, 1972, p 439-448.

Paul, E A, Campbell, C A, Rennie, D A, and McCallum, K J, 1964, Investigations of the dynamics of soil humus using carbon dating techniques: 8 th internatl cong soil sci, Proc, Bucharest 1964, III, p 201.

Roch W 1975 , Die Zusammensetzung der organischen Substanz eines fossilen Torfsandes aus einer Sandgrube bei Walsrode in der Südheide: Telma, v 5, p 189-204.

Scharpenseel, H W, 1972, Messungen der natürlichen C-14 Konzentration in der organischen Substanz von rezenten Böden, eine Zwischenbilanz: Zeitschr Pflanzenernähr, Bodenkunde, v 133, p 241-263. 
Scharpenseel, H W, 1976, The search of biologically inert and lithogenic carbon in recent soil organic matter: IAEA/FAO Internatl symposium on soil organic matter studies Proc, Brunswick FRG, 1976, in press.

Scharpenseel, H W and Pietig, F, 1969, Einfache Boden-und Wasserdatierung durch Messung der ${ }^{14} \mathrm{C}$-und Tritium-Konzentration: Geoderma, v 2, p 273-289.

Vereinfachte, Altersbestimmung mit dem Flüssigkeits Szintillations Spektrometer; Vereinfachte Benzolsynthese, auch aus kleinen $\mathrm{CO}_{2}$-Mengen: Atompraxis, v 16 , no.
2, p 1-2. p p 35 p 266, 267 p 163. charpenseel, H W, Pietig, F, and Schiffmann, H, 1976, Hamburg University radiocarbon dates I: R, v 18, p 269, 273, 282, 283 .

Scharpenseel, H W, Pietig, F, and Tamers, M A, 1968, Bonn radiocarbon measurements I: R, v 10, p 20. 